\title{
Effect of White Mulberry (Morus albas 1.) on Common Carp Performance, Biological Parameters, and Blood Picture
}

\author{
Nasreen Mohi Alddin Abdulrahman* \\ College of Veterinary Medicine, University of Sulaimani, Sulaimaniya, Iraq. \\ *Corresponding Author, Nasreen M. Abdulrahman, E-Mail: nasreen.abdulrahman@univsul.edu.iq
}

\begin{abstract}
As mulberry is being exploited by sericulture, pharmaceutical, cosmetic, food and beverage industries along with its utilization in environmental safety approach; it is appropriate to call it as the most suitable plant for sustainable development. So the aim of using Morus alba $\mathrm{L}$. is to examine its ability to enhance common carp growth performance, biological and some hemato-biochemical parameters. This study has evaluated the growth performance and health performance of common carp (Cyprinus carpio L.) isoenergetic with isonitrogenous diets supplemented with ( (T1 group), (T2 group), (T3 group), 0, 10,15gm of mulberry fruit powder, respectively ) for 12 weeks in the laboratory of fish diseases, College of Veterinary Medicine, University of Sulaimani. Results revealed that the T3 group was significantly higher than other treatments concerning growth performance and feed utilization parameters. The addition of white mulberry fruit powder significantly increased RBC's count and PCV \% in the T3 group. Cholesterol, triglyceride, and HDL were significantly higher in the T3 group, while LDL was significantly lower in the T3 group. The present study revealed that diets supplemented with mulberry increased common carp growth and health performance (Cyprinus carpio).
\end{abstract}

Keywords: Biological Parameters, Blood Picture, Common Carp, Original Article:

DOI:https://dx.doi.org/10.21608/javs $\underline{.2021 .86056 .1089}$

Received:13 July, 2021.

Accepted :22 August, 2021.

Published in October, 2021.

This is an open access article under the term of the Creative Commons Attribution 4.0 (CC. BY) International License. To view a copy of this license, visit:

http://creativecommons.org/licenses/by/4.0/ Performance, White Mulberry.

\section{INTRODUCTION}

Tropical and subtropical fruit species mulberry (Morus spp.) are involved in the genus Morus and the family Moraceae (Ozrenk et al., 2010). East, West and South East Asia, South Europe, South of North America, Northwest of South America and some parts of Africa are distribution areas of Morus spp. The most commonly grown species in the Morus genus are white mulberry, black mulberry, and red mulberry (Ozgen $e t$ al., 2009).

Morus albas L. (Moraceae) white mulberry has a long history in Chinese medicine. White mulberry is cultivated through leaves is the main food source for silkworms. Traditionally, the white mulberry plant has been used to treat weakness, fatigue, anemia, dizziness and constipation in elderly patients because of its analgesic, antiasthmatic, antirheumatic, expectorant, hypotensive and brain tonic effects (Al-Kennany $\boldsymbol{e t}$ al., 2009).
Ozgen et al., (2009) stated that mulberry had essential effects on human health with the help of its antioxidant contents. The demand for fruit species containing anthocyanins and anthocyanidins has been increased due to the identification of anticarcinogenic effects of flavonoids in a recent study. Gundogdu $\boldsymbol{e t}$ al., (2011) determined that chlorogenic acid and antioxidant contents in the fruit of Morus nigra were found to be quite higher than those of M. alba and $M$. Rubra. It has been reported that phenolic compounds such as widely prevailing chlorogenic acid and catechins have antimutagenic and anticarcinogenic features. Moreover, nitrosamines suspected to cause cancer are blocked with cinnamic acids, a sub-group of phenolic acids (Cemeroglu et al., 2004).

Mulberry is also used as a medicinal plant in improving and enhancing the life of human beings by utilizing the biologically active pharmacokinetic compounds found in leaf, stem and root parts. Further industrial exploitation of mulberry through preparation gained the attention of industrialists. As mulberry is 
being exploited by sericulture, pharmaceutical, cosmetic, food and beverage industries and its utilization in environmental safety approach; it is appropriate to call it the most suitable plant for sustainable development (Rohela et al., 2020). So the aim of using Morus alba L. is to examine its ability to enhance common carp growth performance, hematological and biochemical parameters, and meat quality.

\section{MATERIIALS AND METHODS}

\section{Preparation of Herbal powder:}

White mulberry fruit obtained from local markets in march due that it was its season and very cheap, dried in sunlight for several days, making its powder by mincing in the same mincer used in the College of Veterinary Medicine.

\section{Diet and Treatments:}

$M$. alba with different concentrations were incorporated into a commercial diet where: $\mathrm{T} 1$; a commercial diet without any supplement, T2 a commercial diet supplemented with $10 \mathrm{~g} / \mathrm{Kg}$; and $\mathrm{T} 3$ supplemented with $15 \mathrm{~g} / \mathrm{Kg}$ diet.

Proximate chemical composition for moisture, crude protein, total lipids, and ash contents was determined according to the standard methods of AOAC (2005) (Table 1).

Table 1: Chemical composition of different diet treatments

\begin{tabular}{|cccc|}
\hline $\begin{array}{c}\text { Ingredient } \\
\text { (Percentage \%) }\end{array}$ & $\begin{array}{c}\text { T1 } \\
\text { (Control } \\
\text { group) }\end{array}$ & $\begin{array}{c}\text { T2 } \\
\text { ( Group }\end{array}$ & $\begin{array}{c}\text { T3 } \\
\text { ( Group } \\
3 \text { ) }\end{array}$ \\
\hline Crude Protein & 29 & 29 & 29 \\
Crude Fat & 2.2 & 2.2 & 2.2 \\
Dry Matter & 87.4 & 87.4 & 87.4 \\
Crude Fiber & 4.7 & 4.7 & 4.7 \\
White mulberry & 0 & 10 & 15 \\
fruit powder & & & \\
\hline
\end{tabular}

\section{Fish and Rearing System:}

Common carp ( Cyprinus carpio L.) was brought from local earthen ponds located in Daqoq, north of Iraq, and acclimated to laboratory conditions for three weeks during which fish fed on a commercial diet (28\% crude protein). At the end of the acclimation period, 135 fish (95-105 g) were distributed in nine 100-L tanks at a density of 15 fish per tank. Each tank is provided with compressed air via air stones connected to an air pump. During the experiment, some of the water quality parameters were 5.41-5.11, 23-25 and 7.1-7.4 in each of Oxygen concentration, temperature, and $\mathrm{pH}$, respectively. Fish fed thrice times a day at 9:00, 13:00, and 17:00 h for 12 weeks with 3 $\%$ body weight. A half of each tank's water, along with fish wastes, will be siphoned every day and replaced by well-aerated dechlorinated to maintain water quality along with the experiment.

\section{Growth performance:}

At the end of the experimental time, fish from each tank were collected, counted, and group-weighed. Parameters of fish growth and feed utilization were calculated according to Brown (1957) as follows:

- Weight gain $(\mathrm{g})=\mathrm{W} 2-\mathrm{W} 1$.

- $\quad$ Specific growth rate $(\mathrm{SGR} ; \% \mathrm{~g} /$ day $)=100[\mathrm{Ln}$ $\mathrm{W} 2(\mathrm{~g})-\mathrm{Ln} \mathrm{W} 1(\mathrm{~g})] / \mathrm{T}$.

where $\mathrm{W} 1$ is the initial weight $(\mathrm{g}), \mathrm{W} 2$ is the final weight ( $\mathrm{g}$ ), and $\mathrm{T}$ is the feeding period (day);

The relative growth rate was calculated according to the method described by Brown, (1957) where:

- Relative growth rate $(\mathrm{RGR} \%)=$ Weight gain/Initial weight $\times 100=\mathrm{W} 2-\mathrm{W}_{1} / \mathrm{W}_{1} \times 100$.

- The specific growth rate was calculated according to the method described by Uten, (1978).

- Specific growth rate (SGR) $\%=($ Ln final body weight-Ln initial body weight)/ experimental period $) \times 100=(($ Ln W2-Ln W1 $) / T) \times 100$.

- Feed conversion ratio $(\mathrm{FCR})=$ Total feed fed (gm.)/ Total wet weight gain $(\mathrm{g})$.

- $\mathrm{FCR}=$ Total feed/ Total wet weight gain

- Feed efficiency ratio (FER) = Total weight gain (gm.)/ Total feed fed (gm.) according to Uten (1978).

- The protein efficiency ratio was calculated as: Protein efficiency ratio $(\mathrm{PER})=$ Total wet weight gain (gm/fish)/ Amount of protein fed (gm./fish) according to Uten (1978).

- Fat efficiency ratio (FER) = Total wet weight gain (gm/fish)/ Amount of fat fed (gm./fish) according to Uten (1978).

\section{Biological parameters:}

At the end of the experimental period, five fish were randomly taken from each tank, anesthetized with clove powder (30 mg/L) (Hassan, 2016) and blood samples were collected from the caudal vein. Fish weight and total length were recorded. Fish dissected where liver, gills, viscera, and kidney removed and weighed.

The organs-somatic indices of fish were calculated as follows:

- Condition $(\mathrm{K})$ factor $=100$ (fish weight; $\mathrm{g}) /(\text { fish length; } \mathrm{cm})^{3}$ (Lagler, 1956). 
- Hepatic somatic index (HSI, \%) = 100 (liver weight (g)/fish weight (g)) (Lagler, 1956).

- The following indices were calculated according to Abdulrahman et al., (2018).

- Gills somatic index (GSI, \%) = 100 (gills weight (g)/fish weight $(\mathrm{g}))$.

- Kidney somatic index $(\mathrm{KSI}, \%)=100$ (kidney weight (g)/fish weight $(\mathrm{g}))$.

- $\quad$ Spleen somatic index (SSI, \%) $=100$ (kidney weight $(\mathrm{g}) /$ fish weight $(\mathrm{g}))$.

- Intestine Length Index (According to fish Length) $=100$ (Intestine length $(\mathrm{cm}) /$ fish length $(\mathrm{g})$ ).

- Intestine Length Index (According to fish Weight) $=100$ (Intestine length $(\mathrm{cm}) /$ fish weight $(\mathrm{g}))$.

- Intestine Weight Index = 100 (Intestine length (cm)/fish weight (g)).

- Weight without Viscera Index $=100$ (Fish weight / Fish Weight without Viscera.

- $\quad$ Weight without Viscera \& Head = 100 (Fish weight / Fish Weight without Viscera \& Head.

\section{Hematological parameters:}

Blood samples obtained from the caudal vein were divided into two sets of Eppendorf tubes. The first set contained sodium heparinate $(20 \mathrm{U} / \mathrm{L})$, as an anticoagulant, for analyzing hematological parameters including white blood cells (WBC's) count, red blood cells (RBC's) count, hemoglobin $(\mathrm{Hb})$ concentration,
PCV \% Platelets count and hematological indices ( $\mathrm{MCV}, \mathrm{MCH}, \mathrm{MCHC}$ ) according to Feldeman et al., (2000). The second set was left with no anticoagulant in order to clot at $4^{\circ} \mathrm{C}$ and centrifuged at $5000 \times \mathrm{g}$ for $20 \mathrm{~min}$ at room temperature to obtain serum for measuring the different biochemical parameters.

\section{Biochemical parameters:}

Serum biochemical analyses including glucose, total protein, total cholesterol, high-density lipoprotein cholesterol (HDL), low-density lipoprotein cholesterol (LDL), very low-density lipoprotein (VLDL), triglycerides, aspartate aminotransferase (AST), and alanine aminotransferase (ALT) were determined using an automatic biochemical analyzer using commercial kits from Spinreact, S.A. (Gerona, Spain) (Abdulrahman et al., 2020).

\section{8. statistical analysis:}

Prior to statistical analysis, all data were tested for normality of distribution using the KolmogorovSmirnov test. The homogeneity of variances among different treatments will be tested using Bartlett's test. Then, data will be subjected to one-way ANOVA to evaluate the effects of different feed supplementation. Duncan's test is used as a post hoc test to compare between treatments at $P<0.05$. All the statistical analyses were done via SPSS program version 20 (SPSS, Richmond, VA, USA) (Dytham, 2011).

\section{RESULTS}

As shown in Table 2, regarding the effect of white mulberry (Morus albas L.) fruit powder on common carp, the T3 group with $15 \mathrm{~g} / \mathrm{kg}$ was significantly higher than other treatments in each growth performance and feed utilization parameter.

Table 2: Effect of white mulberry (Morus albas L.) fruit powder on common carp growth performance and feed utilization

\begin{tabular}{|cccccccc|}
\hline Treatments & Wt. Gain & $\begin{array}{c}\text { Specific } \\
\text { Growth Rate }\end{array}$ & $\begin{array}{c}\text { Relative } \\
\text { Growth Rate }\end{array}$ & $\begin{array}{c}\text { Feed } \\
\text { Conversion } \\
\text { Ratio }\end{array}$ & $\begin{array}{c}\text { Feed } \\
\text { Efficiency } \\
\text { Ratio }\end{array}$ & $\begin{array}{c}\text { Protein } \\
\text { Efficiency } \\
\text { Ratio }\end{array}$ & $\begin{array}{c}\text { Fat } \\
\text { Efficiency } \\
\text { Ratio }\end{array}$ \\
\hline T1 group & $\begin{array}{c}27.080^{\mathrm{b}} \pm \\
0.194\end{array}$ & $0.150^{\mathrm{a}} \pm$ & $21.334^{\mathrm{c}} \pm$ & $2.249^{\mathrm{a}} \pm$ & $45.128^{\mathrm{b}} \pm$ & $0.934^{\mathrm{b}} \pm$ & $11.309^{\mathrm{b}} \pm$ \\
& 0.005 & 1.05 & 0.04 & 2.14 & 0.05 & 1.06 \\
& & & & & & & \\
T2 group & $28.565^{\mathrm{b}} \pm$ & $0.192^{\mathrm{a}} \pm$ & $28.145^{\mathrm{b}} \pm$ & $2.052^{\mathrm{a}} \pm$ & $49.084^{\mathrm{b}} \pm$ & $0.985^{\mathrm{b}} \pm$ & $12.984^{\mathrm{b}} \pm$ \\
& 0.24 & 0.004 & 1.07 & 0.07 & 1.56 & 0.03 & 1.06 \\
& & & & & & & \\
T3 group & $\begin{array}{c}2.470^{\mathrm{a}} \pm \\
0.34\end{array}$ & $0.209^{\mathrm{a}} \pm$ & $31.024^{\mathrm{a}} \pm$ & $1.622^{\mathrm{b}} \pm$ & $62.021^{\mathrm{a}} \pm$ & $1.120^{\mathrm{a}} \pm$ & $14.759^{\mathrm{a}} \pm$ \\
& 0.001 & 1.14 & 0.07 & 2.04 & 0.09 & 1.90 \\
\hline
\end{tabular}

Different letters in the same rows mean significant differences $(\mathrm{p}<0.05)$. 
Table 3: Effect of white mulberry (Morus albas L.) fruit powder on common carp bio-physiological indices

\begin{tabular}{|lccccc|}
\hline Treatments & $\begin{array}{c}\text { Hepatosomatic } \\
\text { index }\end{array}$ & $\begin{array}{c}\text { Spleen somatic } \\
\text { index }\end{array}$ & $\begin{array}{c}\text { Gill somatic } \\
\text { index }\end{array}$ & $\begin{array}{c}\text { Kidney somatic } \\
\text { index }\end{array}$ & $\begin{array}{c}\text { Condition } \\
\text { Factor }\end{array}$ \\
\hline T1 group & $1.476^{\mathrm{a}} \pm 0.02$ & $0.163^{\mathrm{a}} \pm 0.04$ & $6.104^{\mathrm{a}} \pm 0.01$ & $0.307^{\mathrm{a}} \pm 0.01$ & $1.528^{\mathrm{a}} \pm 0.01$ \\
T2 group & $1.672^{\mathrm{a}} \pm 0.01$ & $0.194^{\mathrm{a}} \pm 0.05$ & $5.205^{\mathrm{a}} \pm 0.01$ & $0.459^{\mathrm{a}} \pm 0.01$ & $1.412^{\mathrm{a}} \pm 0.01$ \\
T3 group & $1.807^{\mathrm{a}} \pm 0.02$ & $0.132^{\mathrm{a}} \pm 0.04$ & $6.282^{\mathrm{a}} \pm 0.01$ & $0.373^{\mathrm{a}} \pm 0.01$ & $1.610^{\mathrm{a}} \pm 0.02$ \\
\hline
\end{tabular}

Different letters in the same rows mean significant differences $(\mathrm{p}<0.05)$

No significant differences were observed in Intestine Weight Index among treatments; the T2 group was higher significantly in Intestine Length Index in both fish weight and length, as seen inTable 4.

Table 4: Effect of white mulberry (Morus albas L.) fruit powder on common carp intestine indices

\begin{tabular}{|cccc|}
\hline Treatments & $\begin{array}{c}\text { Intestine Weight } \\
\text { Index }\end{array}$ & $\begin{array}{c}\text { Intestine Length Index } \\
\text { (According to fish } \\
\text { Weight) }\end{array}$ & $\begin{array}{c}\text { Intestine Length Index } \\
\text { (According to fish } \\
\text { Length) }\end{array}$ \\
\hline T1 group & $1.730^{\mathrm{a}} \pm 0.02$ & $19.696^{\mathrm{b}} \pm 0.03$ & $139.642^{\mathrm{b}} \pm 1.24$ \\
T2 group & $2.043^{\mathrm{a}} \pm 0.02$ & $22.359^{\mathrm{ab}} \pm 0.0 .3$ & $139.524^{\mathrm{b}} \pm 1.24$ \\
T3 group & $2.339^{\mathrm{a}} \pm 0.02$ & $23.541^{\mathrm{a}} \pm 0.02$ & $158.182^{\mathrm{a}} \pm 1.22$ \\
\hline
\end{tabular}

Different letters in the same rows mean significant differences $(\mathrm{p}<0.05)$.

Fish weight without viscera and/ or head were significantly higher in the T2 group as shown in table 5.

Table 5: Effect of white mulberry (Morus albas L.) fruit powder on common carp meat indices

\begin{tabular}{|ccc|}
\hline Treatments & Wt. without Viscera Index & $\begin{array}{c}\text { Wt. without Viscera \& Head } \\
\text { Index }\end{array}$ \\
\hline T1 group & $78.974^{\mathrm{bc}} \pm 1.04$ & $59.251^{\mathrm{b}} \pm 1.08$ \\
T2 group & $80.505^{\mathrm{b}} \pm 1.05$ & $59.452^{\mathrm{b}} \pm 1.04$ \\
T3 group & $83.576^{\mathrm{a}} \pm 1.02$ & $62.683^{\mathrm{a}} \pm 1.03$ \\
\hline
\end{tabular}

Different letters in the same rows mean significant differences $(\mathrm{p}<0.05)$

Table 6 showed that the addition of white mulberry (M. albas L.) fruit powder significantly increased RBC's count, WBC's count and PCV \% in the T3 group ( $15 \mathrm{~g} / \mathrm{kg}$ diet) of than the control group (T1) and T2 group. The control group (T1) was significantly higher in each $\mathrm{MCH}, \mathrm{MCHC}, \mathrm{MCV}$, and Platelet count. No significant differences were observed in hemoglobin concentration.

Table 6: Effect of white mulberry (Morus albas L.) fruit powder on common carp hematological parameters.

\begin{tabular}{|ccccccccc|}
\hline \multirow{2}{*}{ Treatments } & $\begin{array}{c}\mathrm{RBC}^{\prime} \mathrm{s} \\
\left(10^{6} / \mu \mathrm{L}\right)\end{array}$ & $\begin{array}{c}\text { WBCs } \\
\left(10^{3} / \mu \mathrm{L}\right)\end{array}$ & $\begin{array}{c}\mathrm{HB} \\
(\mathrm{g} / \mathrm{dl})\end{array}$ & $\begin{array}{c}\text { PCV } \\
(\%)\end{array}$ & $\begin{array}{c}\mathrm{MCH} \\
(\mathrm{pg})\end{array}$ & $\begin{array}{c}\text { MCHC } \\
(\mathrm{g} \%)\end{array}$ & $\begin{array}{c}\text { MCV } \\
(\mathrm{fL})\end{array}$ & $\begin{array}{c}\text { PLT } \\
\left(10^{3} / \mu \mathrm{L}\right)\end{array}$ \\
\hline \multirow{2}{*}{ T1 group } & $6.90^{\mathrm{b}} \pm$ & $10.40^{\mathrm{b}}$ & $9.10^{\mathrm{ab}} \pm$ & $14.90^{\mathrm{b}} \pm$ & $131.40^{\mathrm{a}} \pm$ & $61.2500^{\mathrm{a}}$ & $21.71^{\mathrm{a}} \pm$ & $150.0^{\mathrm{a}} \pm$ \\
& $0.004^{2}$ & \pm 0.005 & 0.74 & 0.14 & 1.25 & \pm 1.54 & 1.24 & 0.17 \\
T2 group & $9.00^{\mathrm{b}} \pm$ & $10.658^{\mathrm{b}}$ & $9.00^{\mathrm{ab}} \pm$ & $16.95^{\mathrm{b}}$ & $112.85^{\mathrm{b}} \pm$ & $58.20^{\mathrm{b}} \pm$ & $20.28^{\mathrm{b}} \pm$ & $105.0^{\mathrm{b}}$ \\
& 0.007 & \pm 0.004 & 0.51 & \pm 0.11 & 1.21 & 1.09 & 1.06 & \pm 0.41 \\
T3 group & $11.00^{\mathrm{a}} \pm$ & $11.059^{\mathrm{a}}$ & $9.25^{\mathrm{a}} \pm$ & $22.65^{\mathrm{a}}$ & $85.30^{\mathrm{c}} \pm$ & $44.25^{\mathrm{c}} \pm$ & $19.24^{\mathrm{c}}$ & $105.0^{\mathrm{b}}$ \\
& 0.001 & \pm 0.008 & 0.91 & \pm 0.24 & 1.97 & 1.20 & \pm 1.09 & \pm 0.27 \\
\hline
\end{tabular}

Different letter in the same rows mean significant differences $(\mathrm{p}<0.05)$ 


\section{Nasreen Mohi Alddin Abdulrahman}

Cholesterol, triglyceride and HDL were significantly higher in T3group according to the control group (T1) and T2 group, LDL was significantly higher in the control group (T1), and no significant differences were observed in VLDL seen in Table (7).

Table 7: Effect of white mulberry (Morus albas L.) fruit powder on common carp lipid profile

\begin{tabular}{|c|c|c|c|c|c|}
\hline Treatments & $\begin{array}{c}\text { Cholesterol } \\
(\mathrm{mg} / \mathrm{dl})\end{array}$ & $\begin{array}{c}\text { Triglyceride } \\
(\mathrm{mg} / \mathrm{dl})\end{array}$ & $\mathrm{LDL}(\mathrm{U} / \mathrm{L})$ & $\begin{array}{l}\text { HDL } \\
\text { (U/L) }\end{array}$ & $\begin{array}{l}\text { VLDL } \\
\text { (U/L) }\end{array}$ \\
\hline $\mathrm{T} 1$ group & $88.25^{\mathrm{b}} \pm 0.15$ & $181.00^{\mathrm{bc}} \pm 0.14$ & $\begin{array}{l}20.75^{\mathrm{a}} \\
\pm 1.11\end{array}$ & $38.70^{\mathrm{c}} \pm 0.04$ & $\begin{array}{c}38.85^{\mathrm{a}} \\
\pm 0.01\end{array}$ \\
\hline $\mathrm{T} 2$ group & $89.00^{\mathrm{b}} \pm 0.14$ & $185.40^{\mathrm{b}} \pm 0.12$ & $\begin{array}{c}17.60^{\mathrm{b}} \\
\pm 0.97\end{array}$ & $46.45^{\mathrm{b}} \pm 0.01$ & $\begin{array}{l}37.10^{\mathrm{a}} \\
\pm 0.01\end{array}$ \\
\hline $\mathrm{T} 3$ group & $93.65^{\mathrm{a}} \pm 0.11$ & $194.25^{\mathrm{a}} \pm 0.12$ & $\begin{array}{c}17.80^{\mathrm{b}} \\
\pm 0.92\end{array}$ & $56.15^{\mathrm{a}} \pm 0.01$ & $\begin{array}{l}36.20^{\circ} \\
\pm 0.01\end{array}$ \\
\hline
\end{tabular}

Different letters in same rows mean significant differences $(\mathrm{p}<0.05)$

The white mulberry (M. albas L.) fruit powder significantly affects GPT, GOT in the T2 group and the CKI. Blood sugar was higher significantly in the control group (T1), the control group (T1) was significantly higher in each of total protein and albumin ratio, no significant in Globulin ratio as observed in Table 8.

Table 8: Effect of white mulberry (Morus albas L.) fruit powder on common carp serum biochemistry

\begin{tabular}{|cccccccc|}
\hline Treatments & $\begin{array}{c}\text { Glucose } \\
(\mathrm{mg} / \mathrm{dl})\end{array}$ & $\begin{array}{c}\text { GPT } \\
(\mathrm{U} / \mathrm{L})\end{array}$ & $\begin{array}{c}\text { GOT } \\
(\mathrm{U} / \mathrm{L})\end{array}$ & T.P. $(\mathrm{g} / \mathrm{dl})$ & $\begin{array}{c}\text { Albumin } \\
(\mathrm{g} / \mathrm{dl})\end{array}$ & $\begin{array}{c}\text { Globulin } \\
(\mathrm{g} / \mathrm{dl})\end{array}$ & $\begin{array}{c}\text { CKI } \\
(\mathrm{U} / \mathrm{L})\end{array}$ \\
\hline \multirow{2}{*}{ T1 group } & $136.80^{\mathrm{a}}$ & $64.25^{\mathrm{c}} \pm$ & $141.45^{\mathrm{b}}$ & $2.80^{\mathrm{a}}$ & $1.95^{\mathrm{a}}$ & $0.26^{\mathrm{a}}$ & $770.350^{\mathrm{a}}$ \\
& \pm 0.01 & 0.14 & \pm 0.01 & \pm 0.02 & \pm 0.01 & \pm 0.02 & \pm 0.91 \\
T2 group & $125.30^{\mathrm{b}}$ & $98.95^{\mathrm{b}}$ & $122.30^{\mathrm{c}}$ & $2.65^{\mathrm{b}}$ & $1.15^{\mathrm{b}}$ & $0.25^{\mathrm{a}}$ & $284.000^{\mathrm{c}}$ \\
& \pm 0.02 & \pm 0.15 & \pm 0.01 & \pm 0.01 & \pm 0.01 & \pm 0.01 & \pm 1.04 \\
T3 group & $62.10^{\mathrm{c}}$ & $117.60^{\mathrm{a}}$ & $171.85^{\mathrm{a}}$ & $2.59^{\mathrm{bc}}$ & $0.19^{\mathrm{c}}$ & $0.25^{\mathrm{a}}$ & $744.550^{\mathrm{b}}$ \\
& \pm 0.01 & \pm 0.14 & \pm 0.01 & \pm 0.01 & \pm 0.01 & \pm 0.01 & \pm 1.05 \\
\hline
\end{tabular}

Different letters in same rows mean significant differences $(\mathrm{p}<0.05)$

\section{DISCUSSION}

For the first time, the present study was conducted to evaluate the possible effects of dietary supplementation of white mulberry fruit powder on the growth performance, some hemato-biochemical parameters and some biological parameters of common carp. The efficacy of mulberry has been attributed to the flavonoids compounds, which may help in improving the health status and performance of fish (Katsube et al., 2006). Although mulberry is widely used as a medicinal herb globally, no brief studies explained its application as feed additives in aquaculture. Its availability in local markets with benefits makes it used by recent research.

M. alba fruit has a long history of use as an edible fruit and traditional medicine. A great diversity of bioactive compounds, including anthocyanins, rutin, quercetin, chlorogenic acid, and polysaccharides, have been found in mulberry fruit. Furthermore, mulberry fruit has shown numerous biological activities such as antioxidant, neuroprotective, antiatherosclerosis, immunomodulatory, antitumor, antihyperglycemic, and hypolipidemic activities. Natural food products might be safe and eco-friendly without side effects. A study suggested that polyphenolic-rich mulberry could afford potent protection against EC-induced cytotoxicity and oxidative stress (Chen et al., 2017).

Mulberry is listed as a kind of homology of medicine and food in China. A large number of studies have reported that mulberry is rich in flavonoids and anthocyanins which give it a potent antioxidant activity. In addition, mulberry fruits have also been proved to possess various biological activity including antiobesity, antihyperglycemic, and anti-inflammatory effects (Chen $\boldsymbol{e t}$ al., 2017). The results of Alipanah $\boldsymbol{e t}$ al., (2020) showed that silkworms that consumed leaves of mulberry had better performance. Also, they had better performance for traits of cocoon shell weight, feed efficiency to cocoon shell weight, and feed efficiency to cocoon weight. According to the author's review, there is no related study to compare the recent results. 
Growth performance and feed conversion ratio are essential parameters to judge the potential of using feed additives in aquaculture. The present study found that dietary mulberry played an important role in improving the weight gain, specific growth rate, and feed conversion ratio of common carp. Fish fed a diet supplemented with mulberry showed a significant weight gain increase and concurrent FCR decrease. Our observation is inconsistent with previous findings that reported that using medicinal herbs addition increased the growth-related parameters while decreasing feed conversion ratio (Abedalhammed et al., 2017, Acar et al., 2018; Parrino et al., 2019; Zemheri-Navruz et al., 2019, Abdulrahman et al., 2020, Shaima et al., 2020). In fish, monitoring the indices such as hematological parameters can reveal general immune system conditions. However, using high levels of the dietary mulberry $(15 \mathrm{~g} / \mathrm{kg})$ in the present study improved the blood parameter to the point found in the control treatments.

The current study demonstrated that dietary incorporation of mulberry significantly affected growth and feed efficiency in common carp through the improvement of FCR. Berry plants are reported to contain a variety of bioactive compounds such as anthocyanins, flavonols, or ellagitannins (Yilmaz, 2019). Concerning these points, Shekarabi et al., (2020) showed that Growth performance of rainbow trout fed diets enriched with different levels of mulberry juice powder the SGR, WG, and SR values were increased significantly following dietary supplementation with mulberry juice powder in a dosedependent manner with the highest values in fish fed $0.75 \%$. Additionally, the feed conversion ratio (FCR) was decreased when fish were fed mulberry juice powder. Li et al., (2012 ) reported that the improved WG and FCR by dietary herbs are related to improved utilization of nutrients and the activation of the functionality of the intestinal flora.

Stimulation of digestion and enhanced protein assimilation in the intestinal tract of fish takes place via various active compounds of herbs (Kesbiç, 2019; Kim et al., 2019; Yilmaz, 2019 b). Further, Van Doan et al., (2019 b) reported that herbs, such as Thai ginseng (Boesenbergia rotunda) powder and elephant's foot (Elephantopus scaber) extract, can stimulate digestion in Nile tilapia through a possible increase in digestive enzyme activity. Chemical composition of rainbow trout fed diets in Shekarabi et al., (2020) enriched with different levels of mulberry juice powder after 8 weeks. Body crude protein and moisture contents were increased significantly in fish-fed mulberry juice powder at 0.5 and $0.75 \%$. In contrast, fish showed improved lipid content by feeding mulberry supplemented at $0.25,0.5$, and $0.75 \%$ compared to the control group. On the other hand, body ash content was increased in a fish-fed mulberry enriched diet. Interestingly, mulberry supplementation increased the body's protein and lipid contents. This may be attributed to its role in enhancing the protein and lipid metabolism-related to improved feed utilization.

Blood biochemical and physiological markers, for example, serum compounds, could be utilized to recognize the probable beneficial effects of using natural feed additives on the health status of aquatic animals (Zaineldin et al., 2018). Blood cortisol and glucose contents are among the important signs against environmental stressors in fish (Dawood et al., 2017). High blood glucose levels result from increased cortisol levels, which would promote gluconeogenesis in the liver (Leach and Taylor, 1982). In this study, glucose levels decreased in fish-fed mulberry when compared with the control group. The significantly lower glucose levels in blood suggested that mulberry had an antistress effect and inhibited the amplitude of elevated cortisol, thereby reducing the magnitude of elevated glucose levels in the blood.

The results also showed that from the dietary inclusion levels of the mulberry used in the present study $(0,10$, and $15 \mathrm{~g} / \mathrm{kg})$, the dietary supplement of 15 $\mathrm{g} / \mathrm{kg}$ was the most effective in improving the performance. Several herbal plants also were tested for their growth-promoting activity in aquatic animals such as Jayaprakas and Euphrasia, on hRohu (Labeo rohita) fish, Date Palm Seeds (Phoenix dactyliferous L.) by Ahmed et al., (2017) and Hama et al., (2019) using alfalfa leaves powder on common carp. In addition, $\mathrm{Wu}$ et al. showed that the supplementation of Gynostemma pentaphyllum, traditional herbal medicine in China, to grass carp feed resulted in an increase in FCR, weight gain, and growth rate. These reflect the improvements in the nutritional balance and in immunity enhancement in fish.

To find efficacious drugs to control Ichthyophthirius multifiliis (Ich), the root bark of white mulberry M.s alba was evaluated for its antiprotozoal activity. Bark was powdered and extracted with 1 of 5 organic solvents: Low concentrations (2 and 4 mg 1-1) of acetone and ethyl acetate extracts could not kill all theronts after $4 \mathrm{~h}$ exposure, but a significant decrease in the front infectivity was observed following $30 \mathrm{~min}$ of pretreatment with the extracts. $M$. alba extract may be a potential new, safe, and efficacious drug to control Ich (Fu et al., 2014). Antiviral activities of M. alba juice and seed were examined using time-of-addition plaque assays against influenza viruses; its results suggest that mulberry juice can be developed as a novel 
plant-derived antiviral against influenza viruses (Kim and Chung, 2018).

Fujaya, et al., (2014) show that mulberry extract significantly influences the survival rate, stage growth, and the mortality rate of blue swimming crab larvae due to molting syndrome. The higher the dose of ME in the artificial food, the higher the survival rate and the lower the mortality rate due to molting syndrome. These studies indicated that irrespective of the lutein and $\beta$-carotene content of the mulberry leaves in the diet, the fancy carp can convert them to astaxanthin in serum (Yuangsoi et al., 2010). Fish fed all the diets metabolized the carotenoids to astaxanthin, resulting in increased serum levels of this compound. This work suggests the novel approach of using natural plant leaves to replace synthetic carotenoids in aquaculture diets (Yuangsoi et al., 2010).

\section{CONCLUSION}

According to the results observed in our study the addition of 10 and 15 gm white mulberry has benefits to common carp growth and health performance, so it is recommended to be added in aquaculture.

\section{Declaration of Conflicting Interests}

The authors revealed that there was no potential conflicts of interest.

\section{REFERENCES}

ABDULRAHMAN, N. M., SLEMAN, H. D., RAMZI, D. O. M. AND HAMA-SALIH, H. A., 2020. Effect of Chlorella microalgae and germinated barley powder on performance, some health indices, and meat hygiene parameters of common carp (Cyprinus carpio). Basrah Journal of Veterinary Research, 19(3): 218-231. Proceeding of the 17th International Conference. College of Veterinary Medicine. University of Basrah. Iraq.

ABDULRAHMAN, N.M., ABID, S.H., KHIDIR, A.A., OMER, B.B., RASHEED, D.B. AND BAHA ALDDIN, L.H., 2018. Effect of Adding Microalgae Chlorella sp. on Some Biological Parameters and Proximate Analysis of Common Carp Cyprinus carpio L. Iranian Journal of Veterinary Medicine. 12(3): 199.

DOI: 10.22059/ijvm.2018.244747.1004856.

ABEDALHAMMED, H. S., ABDULRAHMAN, N. M. AND SADIK, L., 2017. Comparative study of the effect of natural planting, hydroponic germination and barley sprout powder as prebiotic in common carp Cyprinus carpio L. blood indices. Iraqi Journal of Veterinary Sciences, 31(1): 7-11.

ACAR, Ü., PARRINO, V., KESBIÇ, O. S., LO PPARO, G., SAOCA, C., ABBATE, F., YILMEZ, S. AND FAZIO, F., 2018. Effects of different levels of pomegranate seed oil on some blood parameters and disease resistance against Yersinia ruckeri in rainbow trout. Front. Physiol., 9: 596.
AHMED, V. M., ABDULRAHMAN, N. M., HAMAAMEEN, S. A., HASSAN, B. R., ABBAS, A. B., HUSSEN, B. A., HAMAD, I. S., KAREM, S. A. AND AZIZ, K. M., 2017. Impacts of Date Palm Seeds (Phoenix dactyliferous L.) on Growth Indices and Nutrient Utilization of Common Carp Cyprinus carpio L. Journal of Agricultural Science and Technology, B7: 280-284 doi: 10.17265/21616264/2017.04.005

ALIPANAH, M., ABEDIAN, Z., NASIRI, A. AND SARJAMEI, F., 2020. Nutritional Effects of Three Mulberry Varieties on Silkworms in Torbat Heydarieh. A Journal of Entomology. Volume 2020, Article ID 6483427, $1-4$. https://doi.org/10.1155/2020/6483427.

AL-KENNANY, E.R., AL- AKASHE, M.A. AND ALBAJARI, S. A., 2009. Effect of Mulberry crude extract as antioxidant and antiatherogenic experimentally on rabbit. Al- Anbar J. Vet. Sci., 2 (2): 73- 81.

AOAC., 2005. Official Methods of Analysis of AOAC International. $18^{\text {th }}$ Ed., AOAC International, Gaithersburg, MD, USA, Official Method, 08: 26 pp.

CHEN W., LI, Y., BAO, T. AND GOWD, V., 2017. Mulberry Fruit Extract Affords Protection against Ethyl Carbamate-Induced Cytotoxicity and Oxidative Stress. Oxidative Medicine and Cellular Longevity, Article ID 1594963: 1-12. doi.org/10.1155/2017/1594963.

DAWOOD, M. A., KOSHIO, S., ISHIKAWA, M., ELSABAGH, M., YOKOYAMA, S., WANG, W. L., YUKUN, Z. AND OLIVIER, A., 2017. Physiological response, blood chemistry profile and mucus secretion of red sea bream (Pagrus major) fed diets supplemented with Lactobacillus rhamnosus under low salinity stress. Fish Physiology and Biochemistry, 43: 179-192.

DYTHAM, C., 2011. Choosing and using statistics: A biologist's guide. London: Blackwell Science Ltd. Engström, M. 2016. Understanding the bioactivity of plant tannins: Developments in analysis methods and structure-activity studies. Turku, Finland: Painosalama Oy.

FELDMAN BF, ZINKL JG. AND JAIN NC., 2000. Shalm's Veterinary Hematology (5th edn). Lippincott Williams \& Wilkins, Philadelphia, PA, USA, p. 1344

FU, Y.W., ZHANG, Q., XU, DE-H., XIA, H., CAI, X., WANG, B. AND LIANG, J., 2014. Parasiticidal effects of Morus alba root bark extracts against Ichthyophthirius multifiliis infecting grass carp. Diseases of Aquatic Organisms, 108: 129-136. doi: $10.3354 /$ dao02708

FUJAYA, Y., TRIJUNO, D. D., NIKHLANI, A., CAHYONO, I. AND HASNIDAR, H., 2014. The Use of Mulberry (Morus alba) Extracts in the Mass Production of Blue Swimming Crab (Portunus pelagicus L.) Larvae to Overcome the Mortality Rate Due to Molting Syndrome. Aquatic Science and Technology, 2 (1): 1-14. URL: http://dx.doi.org/10.5296/ast.v2i1.4048.

GUNDOGDU, M., MURADOĞLU, F., SENSORY, R.I. AND YILMAZ, H., 2011. Determination of 
fruit chemical properties of Morus nigra L., Morus alba L. and Morus rubra L. by HPLC. Scientia HorticulTrae 132(1).

DOI: $10.1016 /$ j.scienta.2011.09.035.

HASSAN, B.R., 2016. Impact of clove and mustard as anesthetics on small common carp (Cyprinus carpio L.). Thesis for MSc, University of Sulaimani, College of agricultural sciences, Iraq, p. 125.

KATSUBE， T., IMAWAKA， N., KAWANO, Y., YAMAZAKI, Y., SIWAKU, K. AND YAMANE, Y., 2006. Antioxidant flavonol glycosides in mulberry (Morus alba L.) leaves isolated based on LDL antioxidant activity. Food Chem., 97: 25-31.

KESBIÇ, O. S., 2019. Effects of juniper berry oil on growth performance and blood parameters in common carp (Cyprinus carpio). Aquaculture Research, 50: 342-349.

KIM, H. AND CHUNG, M. S., 2018. Antiviral Activities of Mulberry (Morus alba) Juice and Seed against Influenza Viruses. Evidence-Based Complementary and Alternative Medicine, 2018, Article ID 2606583: 1-10. doi.org/10.1155/2018/2606583.

KIM, J., LEE, K. W., JEONG, H. S., ANSARY, M. W. R., KIM, H. S., KIM, T. AND CHO, S, H., 2019. Oral administration effect of yacon, ginger and blueberry on the growth, body composition and plasma chemistry of juvenile olive flounder (Paralichthys olivaceus) and immunity test against Streptococcus iniae compared to a commercial probiotic, Lactobacillus fermentum. Aquaculture Rep., 15: 100212.

LEACH, G. J. AND TAYLOR, M. H., 1982. The effects of cortisol treatment on carbohydrate and protein metabolism in Fundulus heteroclitus. Gen. Comp. Endocrinol., 48: 76-83.

LI, M. H., OBERLE, D. F. AND LUCAS, P. M., 2012. Effects of dietary fiber concentrations supplied by corn bran on feed intake, growth, and feed efficiency of channel catfish. N. Am. J. Aquac., 74: 148-153.

OZGEN M.A., SERC, SEDAT, E.B. AND KAYA, C., 2009. Phytochemical and antioxidant properties of anthocyanin-rich Morus nigra and Morus rubra fruits. Scientia Horticul Trae. 119: 275-279.

OZRENK K., GAZIOGLU SENSOY R. I., ERDINC C., GULERYUZ, M. AND AYKANAT, A., 2010. Molecular characterization of mulberry germplasm from Eastern Anatolia. African Journal of Biotechnology. 9 (1): 001-006.

PARRINO, V., KESBIÇ, O. S., ACAR, Ü. AND FAZIO, F., 2019. Hot pepper (Capsicum sp.) oil and its effects on growth performance and blood parameters in rainbow trout (Oncorhynchus mykiss). Nat. Prod. Res., 19: 1-5.

ROHELA, G. K., SHUKLA, P., MUTTANNA, KUMAR, R. AND CHOWDHURY, S.R., 2020. Mulberry (Morus spp.): An ideal plant for sustainable development. Trees, Forests and People, 2: 100011. https://doi.org/10.1016/j.tfp.2020.100011.

SHEIKHLAR, A., ALIMON, A. R., DAUD, H., SAAD, C. R., WEBSTER, C. D., MENG, G. Y. AND EBRAHIMI, M., 2014. White Mulberry (Morus alba) Foliage Methanolic Extract Can Alleviate Aeromonas hydrophila Infection in African Catfish
(Clarias gariepinus). The Scientific World Journal, Volume 2014, Article ID 592709, 8 pages

SHEKARABI, S. P., OMIDI, A. H., DAWOOD, M. A. O., ADEL, M. AVAZEH, A. AND HEIDARI, F., 2020. Effect of black mulberry (Morus nigra) powder on growth performance, biochemical parameters, blood carotenoid concentration, and fillet color of rainbow trout. Annual Animal Science, 20(1): 125136. DOI: 10.2478/aoas-2019-0068.

VAN DOAN, H., HOSEINIFAR, S. H., SRINGARM, K., JATURASITHA, S., KHAMLOR, T., DAWOOD, M. A., ESTEBAN, M. A., SOLTANI, M. AND MUSTHAFA, M, S., 2019. Effects of elephant's foot (Elephantopus scaber) extract on growth performance, immune response, and disease resistance of Nile tilapia (Oreochromis niloticus) fingerlings. Fish Shellfish Immunology, 93: 328-335.

YILMAZ, S., 2019. Effects of dietary blackberry syrup supplement on growth performance, antioxidant, and immunological responses, and resistance of Nile tilapia, Oreochromis niloticus to Plesiomonas shigelloides. Fish Shellfish Immunology, 84: 11251133.

YUAN, Q. AND ZHAO, L., 2017. The Mulberry (Morus Alba L.) Fruit-A Review Of Characteristic Components And Health Benefits. Journal of Agriculture and Food Chemistry. 65(48): 1038310394.

YUANGSOI, B., JINTASATAPORN, O., TABTHIPWON, P. AND KAMEL, C., 2010. Comparative Pharmacokinetics after Feeding Fancy Carp (Cyprinus carpio) with Diets Containing Carotenoids from Natural Sources [Tea (Camellia sinensis), Mulberry (Morus alba), and Cassava (Manihot esculenta) Leaf]. Journal of Planar Chromatography, 23(3): 219-224. DOI: 10.1556/JPC.23.2010.3.10.

ZAINELDIN A. I., HEGAZI, S., KOSHIO, S., ISHIKAWA, M., BAKR, A., EL-KEREDY, A. M., DA-WOOD, M, A. O., DOSSOU, S., WANG, W. AND YUKUN, Z., 2018. Bacillus subtilis as probiotic candidate for red sea bream: Growth performance, oxidative status, and immune response traits. Fish Shellfish Immunology, 79: 303-312.

ZEMHERI-NAVARUZ, F., ACAR, Ü. AND YILMEZ, S., 2019. Dietary supplementation of olive leaf extract increases haematological, serum biochemical parameters and immune-related genes expression level in common carp (Cyprinus carpio) juveniles. Fish Shellfish Immunology, 89: 672-676.?????

ZHOU, Y. B., SANG, B. Y., WAN, X. C., YANG, Y. O., ZHANG, J. L., WELKER, T. L. AND LIU, K., 2015. Effect of dietary Chinese tea on growth performance, disease resistance and muscle fatty acid profile of channel catfish (Ictalurus punctatus). Aquaculture International, 23: 683-698.

How to cite this article:

Nasreen Mohi Alddin Abdulrahman, 2021. Effect of white mulberry (Morus albas 1.) on common carp performance, biological parameters, and blood picture. Journal of Applied Veterinary Sciences, 6 (4): 07 - 14.

DOI:https://dx.doi.org/10.21608/javs.2021.86056.1089 